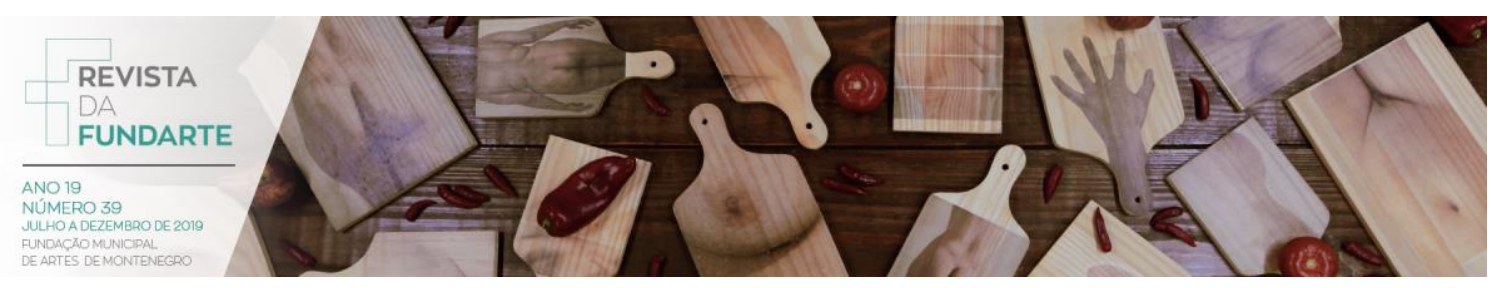

\title{
NARRATIVAS E EXCESSO: RELAÇÕES DAS IMAGENS UBÍQUAS
}

Charmeni Vargas Valandro

VALANDRO, Charmeni Vargas. Narrativas e excesso: relações das imagens ubíquas. Revista da FUNDARTE. Montenegro, p.48-68, ano 19, ํo 39, julho/dezembro de 2019.

Disponível em: http://.seer.fundarte.rs.gov.br/index.php/RevistadaFundarte/index $>20$ de dezembro de 2019. 


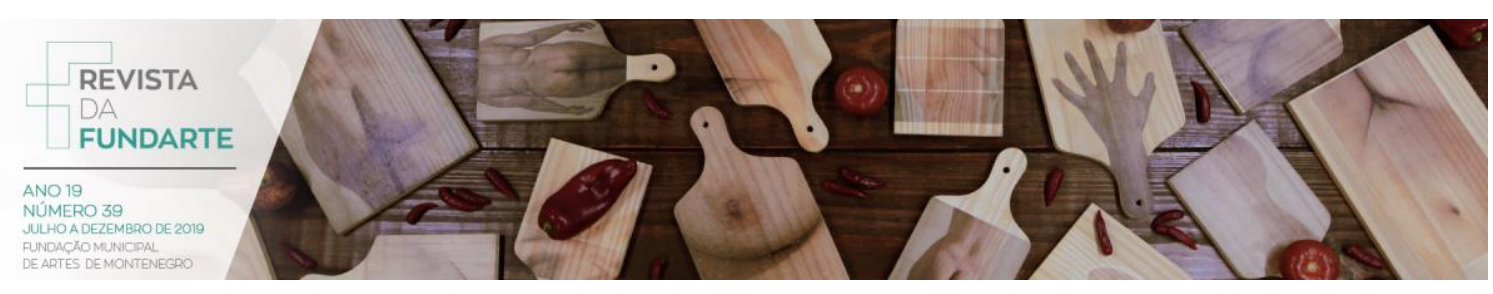

\title{
NARRATIVAS E EXCESSO: RELAÇÕES DAS IMAGENS UBÍQUAS
}

Charmeni Vargas Valandro ${ }^{1}$

Resumo: Esta pesquisa propõem ressignificar os arquivos pessoais encontrados na memória de um aparelho celular correspondente ao período de um ano (2017) através da criação de uma videoinstalação. $O$ texto traz questões referentes a imagens, excesso, narrativas e ubiquidade, sob o viés dos autores pesquisados no referencial teórico, que são, entre outros, Vilém Flusser, Diana Domingues, Julio Plaza, Priscila Arantes e Christine Mello. São abordados também o processo de criação da obra e a interseção entre as linguagens midiáticas e a arte digital. A criação da poética, desta forma se mostra mais na elaboração e desenvolvimento da pesquisa-obra, do que no objeto acabado. Pois, como vídeoinstalção que se instaura no espaço expositivo a posteriori, em relação à escrita deste texto, certamente, ocorrerão percepções que não poderão estar presentes no espaço de reflexão que dá corpo à este artigo.

Palavras-chave: Fotografia; Excesso; Videoinstalação.

\section{NARRATIVES AND EXCESS: RELATIONSHIPS OF UBÍQUAS IMAGES}

\begin{abstract}
This research proposes to resignify the personal files found in the memory of one cell phone, corresponding to the period of one year (2017) through the creation of a video installation. The text presents questions related to images, excess, narratives and ubiquity, under the bias of the authors researched in the theoretical reference, which are, among others, Vilém Flusser, Diana Domingues, Julio Plaza, Priscila Arantes and Christine Mello. The process of creating the work and the intersection between the media languages and digital art are also discussed. Therefore, the creation of poetics is shown more in the elaboration and development of research-work, than in the finished object. For, as a video installation that is established, in relation to the writing of this text, in the exhibition space afterwards, perspectives will certainly occur that could not be present in the space of reflection that gives shape to this article
\end{abstract}

Keywords: Photography; Excess; Video Installation.

\section{INTRODUÇÃO}

Nosso cotidiano é repleto de figuras imagéticas: consumimos imagens nas ruas, nas mídias, nas redes sociais e na vida privada, inclusive, pelos aparelhos celulares. Nos comunicamos através de emojis ${ }^{2}$, nos expressamos por intermédio

\footnotetext{
1 Possui graduação em Comunicação Social - Publicidade e Propaganda - Faculdades Integradas de Taquara (2016). Realiza especialização em Poéticas Visuais - Universidade Feevale (2017) e Curso Comunicação Estratégica com Incidência em Políticas Públicas pela Abong (Associação Brasileira de Organizações Não-Governamentais. É Vice-Coordenadora do Instituto Ambiental Daterra de Permacultura e Sustentabilidade e integrante da Comissão de Ética do Organismo de Controle Social Orgânicos Encosta da Serra Sul Ferrabraz.

2 Emoji é um termo de origem japonesa, composta pela junção dos elementos e (imagem) e moji (letra), e é considerado um pictograma ou ideograma, ou seja, uma imagem (representação gráfica)
}

VALANDRO, Charmeni Vargas. Narrativas e excesso: relações das imagens ubíquas. Revista da FUNDARTE, Montenegro, p. 48-68, ano 19, no 39, julho/dezembro de 2019.

Disponível em: http://.seer.fundarte.rs.gov.br/index.php/RevistadaFundarte/index $>20$ de dezembro de 2019. 


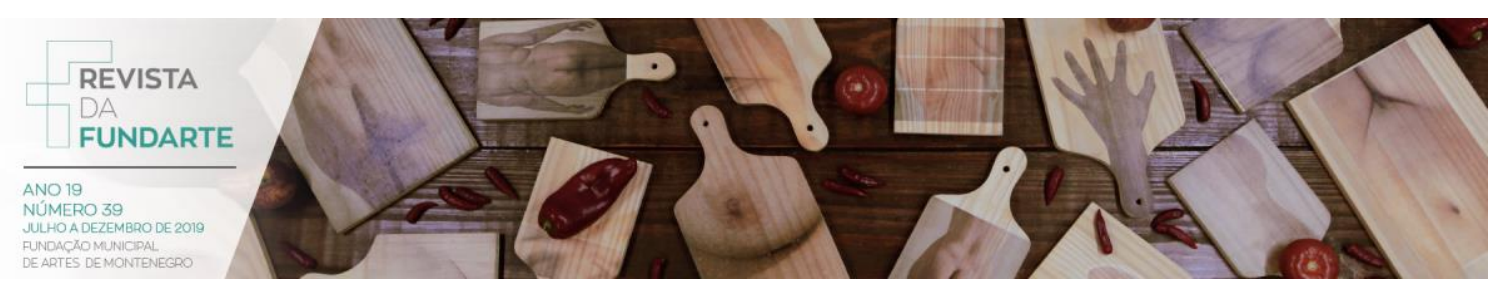

das cores, aprendemos a decifrar formas e composições. As imagens ubíquas ${ }^{3}$ em nossa rotina são, portanto, muito importantes. Porém, tornam-se supérfluas pois se banalizam pelo excesso.

Nesta pesquisa pretendo ressignificar todas as imagens (fotos e vídeos) produzidas, recebidas e arquivadas em meu aparelho celular no ano de 2017, por meio da produção de uma videoinstalação em que proponho um olhar crítico e desnaturalizado àquelas que nos acompanham permanentemente, graças às tecnologias atuais.

A videoinstalação proposta neste trabalho será composta de quatro monitores de tamanho 42 polegadas, nos quais passarão vídeos distintos produzidos por meio da colagem e montagem dos arquivos imagéticos referentes a um trimestre de 2017 cada. Os monitores serão fixados nas paredes de uma cabine que será produzida para a exposição. A cabine terá o tamanho de 1,20m x 1,20m de largura e 2,4m de altura com uma abertura frontal em formato de porta, por onde as pessoas acessam a videoinstalação e recebem os estímulos visuais e sonoros.

Este trabalho, em minha busca, propõe intensificar a fruição do indivíduo que acessa a cabine. Compreendo que existe um elemento de imprevisibilidade nestes vídeos, pois eles têm tempos distintos e não há como prever quais imagens aparecerão concomitante, desta forma, e por estar em looping, o trabalho se modifica à medida que acontece. Essa fruição dialoga com o meio comunicacional dos arquivos, em especial os smartphones e aparelhos mobiles, pois sobressai-se 0 uso individual e até individualista desses aparelhos.

Desta forma, através da videoinstalação, convido as pessoas a acompanhar o período de um ano da minha vida. As aproximo desvendando minhas prioridades, minhas alegrias, minhas angústias e meus amores. Me desnudo, embora minha imagem quase não seja vista. É como um autorretrato forjado pela montagem dos vídeos. Sinto que desta forma, comunicação, arquivamento e memória se

que transmite uma ideia, geralmente são utilizados nas redes sociais para transmitir informação de modo rápido.

${ }^{3}$ Ubíqua: onipresente; que está ou pode estar em toda parte ao mesmo tempo. (Houaiss, Antônio (1915-1999) e Villar, Mauro de Salles (1939-).

VALANDRO, Charmeni Vargas. Narrativas e excesso: relações das imagens ubíquas. Revista da FUNDARTE, Montenegro, p. 48-68, ano 19, ํㅜ 39, julho/dezembro de 2019.

Disponível em: http://.seer.fundarte.rs.gov.br/index.php/RevistadaFundarte/index $>20$ de dezembro de 2019. 


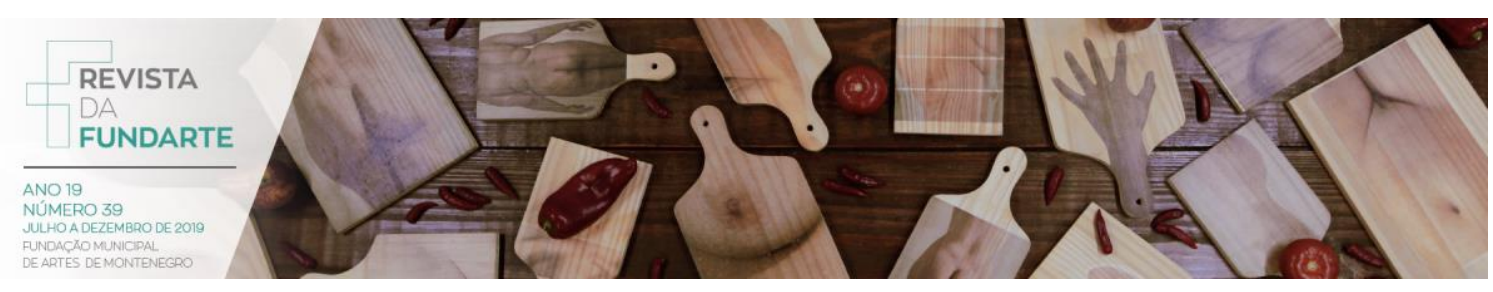

entrelaçam para escancarar a subjetividade da vida, em uma tentativa de ressignificação dos arquivos pessoais.

Para isso, primeiramente, farei uma breve retrospectiva da arte digital, para contextualizar o trabalho dentro da Arte Contemporânea, por conseguinte, parte do Sistema das Artes. Após, abordarei questões referentes a comunicação, tecnologias e mídias com os autores Vilém Flusser, Diana Domingues e Julio Plaza, entre outros, que têm seus estudos voltados para as dinâmicas comunicacionais presentes na arte contemporânea, bem como os suportes e a evolução tecnológica. Em seguida, tratarei do conceito de memória e do processo de arquivamento, principalmente do ponto de vista de Priscila Arantes, que tem uma pesquisa bastante atual e relevante para estes temas. Com embasamento no referencial teórico, incluindo questões pertinentes ao vídeo, por Christine Mello, partirei para o processo em si da construção da obra, percepções do ato criador e identificação de possíveis relações com obras de artistas legitimados pelo Sistema de Artes, para então expor as considerações finais.

\section{ARTE DIGITAL E VIDEOINSTALAÇÃO, BREVE RETROSPECTIVA}

Antes de aprofundar as questões inerentes ao trabalho que proponho, faz-se necessário uma breve viagem pela recente história da arte digital, bem como de seus desdobramentos, entre estes, a vídeo arte e videoinstalação. Percebi tal necessidade diante de possíveis tangências, formais ou conceituais, entre os trabalhos já pertencentes ao Sistema das Artes e a proposta que venho desenvolvendo.

Para falar de imagem hoje, é preciso retornar um pouco na história e pensar os pioneiros de um tipo de imagem que abriu caminho para a massificação imagética pela "reprodutibilidade técnica".

\footnotetext{
${ }^{4} \mathrm{~A}$ reprodutibilidade técnica à qual me refiro ainda é aquela abordada por Benjamin, que previa a perda da aura da obra de arte, a massificação da imagem, porém hoje colocada em situação crítica diante da transformação do conceito de tempo e sua relação com o espaço, exemplo disto, a simultaneidade na troca de informações e a aproximação espacial relativa entre os atores que procedem tais trocas, através das inúmeras tecnologias comunicacionais.
} FUNDARTE, Montenegro, p. 48-68, ano 19, oㅜ 39, julho/dezembro de 2019.

Disponível em: http://.seer.fundarte.rs.gov.br/index.php/RevistadaFundarte/index $>20$ de dezembro de 2019. 


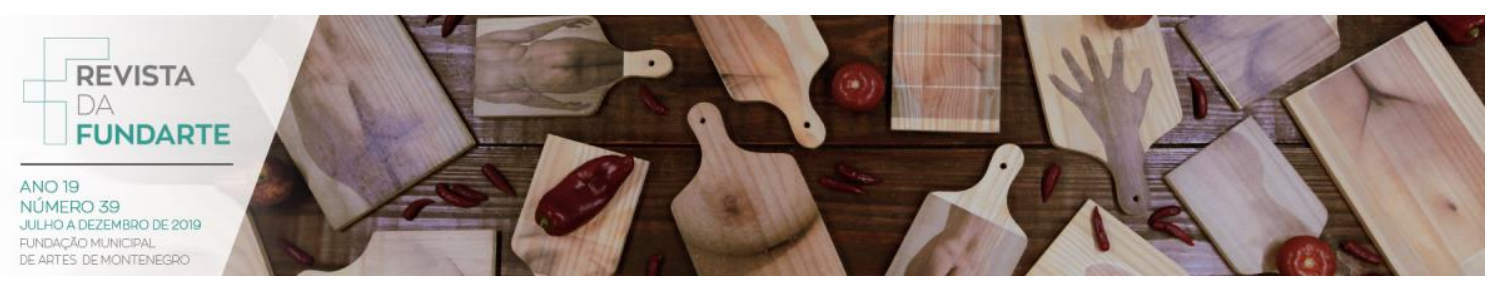

Os pioneiros da fotografia instantânea foram Etienne-Jules Marey (18301904) e Edward Muybridge (1831-1904), influenciados pelos estudos sobre o tempo do filósofo Henri Bergson (1859-1941) e que, por sua vez, influenciaram os futuristas. As fotografias de cavalos de Muybridge (figura 1), em 1878, foram as primeiras a captar o movimento. Em 1890, Thomas Edison (1847-1931) desenvolveu o cinema e em 1895 os irmãos Lumière já projetavam imagens para o público pagante. Dentro de poucos anos, as imagens captadas e auxiliadas pelas fotografias assumiram legitimidade como forma artística no desenvolvimento de uma estética da imagem poética. "A arte e a tecnologia, como representadas pela fotografia e pelo cinema, tornaram-se eternamente interligadas enquanto a dicotomia temática entre arte e vida dissolvia-se aos poucos diante de máquinas ubíquas". (RUSH, p. 14)

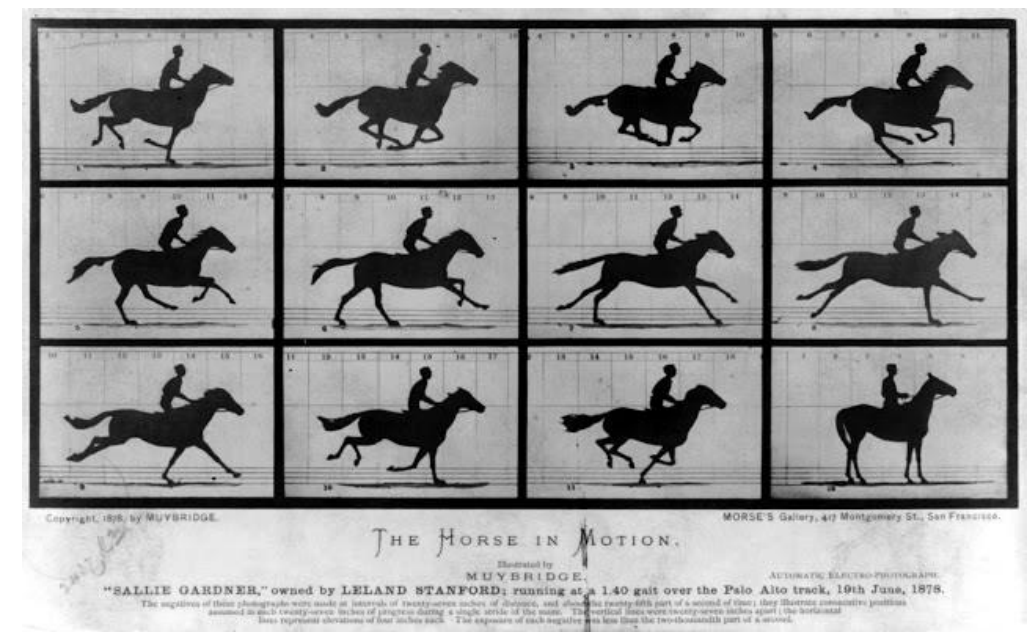

Figura 1: The horse in motion (1878), Edward Muybridge Fonte: http://popcult42.blogspot.com/

Graças a influência do dadaísmo europeu, principalmente, o praticado por Marcel Duchamp (1887-1968), as artes visuais passaram por transformações radicais com a mudança de ênfase do objeto para conceito e a incorporação de novos meios de expressão. Os artistas podiam assim, explorar a criatividade com uma ideia e o papel do acaso na vida e na arte. Neste contexto nasceu o Fluxus, um movimento internacional de artistas, músicos, escritores e cineastas sob a liderança de George Maciunas (1931-1978) que, entre outras obras, desenvolveu aproximadamente 40 filmes de curta metragem criados por diversos artistas. 


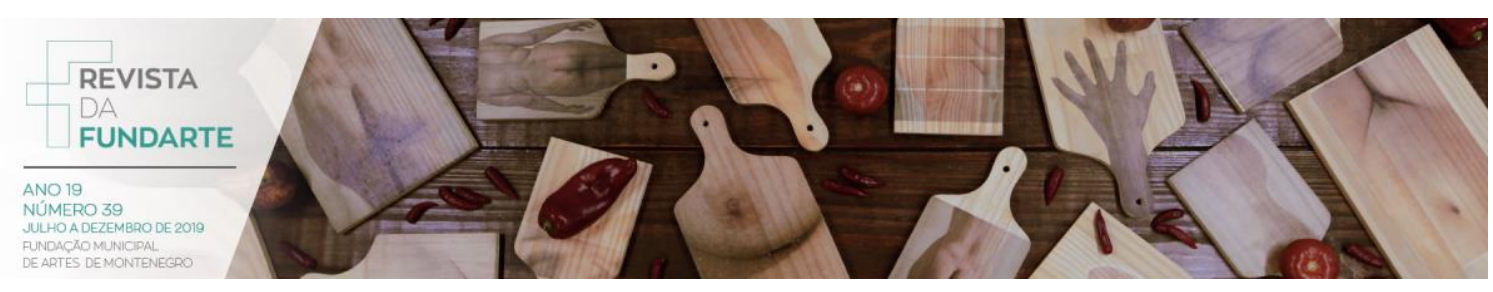

Já uma das primeiras videoartes conhecidas é considerada a captura de imagens, realizada de dentro de um taxi, por Nan June Paik, (integrante do Fluxus) em 1965, em que aparece o Papa passando pela Quinta Avenida, em Nova lorque, e que foi exposto a um grupo de artistas naquela mesma noite. A videoinstalação, por sua vez, surgiu praticamente ao mesmo tempo que a videoarte e mostrou-se como uma contestação às instituições que dominavam os meios de comunicação de massa e como uma abordagem conceitual no qual a forma material é secundária às ideias de arte, além de incorporar práticas de performance, de arte corporal e sonora. "Nesse contexto, a videoarte é arte e comunicação. Filiada à arte conceitual e às linguagens do corpo, a videoarte será, sobretudo, objeto comunicacional resultante da confluência das mídias audiovisuais". (SARZI-RIBEIRO, 2016, p. 71)

A comunicação intrínseca à vídeo arte a qual Sarzi-Ribeiro se refere é ponto crucial no desenvolvimento desta videoinstalação, que está diretamente relacionada aos tipos de arquivos que serão utilizados na produção dos vídeos e ao número excessivo destes, que direciona nosso pensamento para o uso das tecnologias e das mídias digitais e o potencial comunicacional advindo delas, aproximando arte e vida, conhecimentos técnicos e intuição, pesquisa e poética, baseado na interseção das linguagens e no processo de desenvolvimento da obra criado pelo artista, com base em suas relações subjetivas e efetivas com os meios e com o mundo.

Para tentar entender o lugar e a influência do material escolhido como base para a criação dos vídeos, relacionarei os arquivos com os meios de produção, de linguagem e de finalidade.

\section{IMAGENS, COMUNICAÇÃO, TECNOLOGIA E MÍDIAS}

No século $\mathrm{XV}$, as imagens foram mecanizadas junto com os textos científicos ilustrados, por meio da gravura e da imprensa. Para Vilém Flusser (2011), essa inserção das imagens técnicas modificou a maneira como nos relacionamos com o mundo, pois na era da escrita havia um pensamento histórico, racional e linear que foi transformado em um novo pensamento não-linear, pós-histórico, formado pelo retorno da leitura imagética, que aponta para a sociedade forjada no colapso do texto e na hegemonia das imagens midiáticas.

VALANDRO, Charmeni Vargas. Narrativas e excesso: relações das imagens ubíquas. Revista da FUNDARTE, Montenegro, p. 48-68, ano 19, ํo 39, julho/dezembro de 2019.

Disponível em: http://.seer.fundarte.rs.gov.br/index.php/RevistadaFundarte/index $>20$ de dezembro de 2019. 


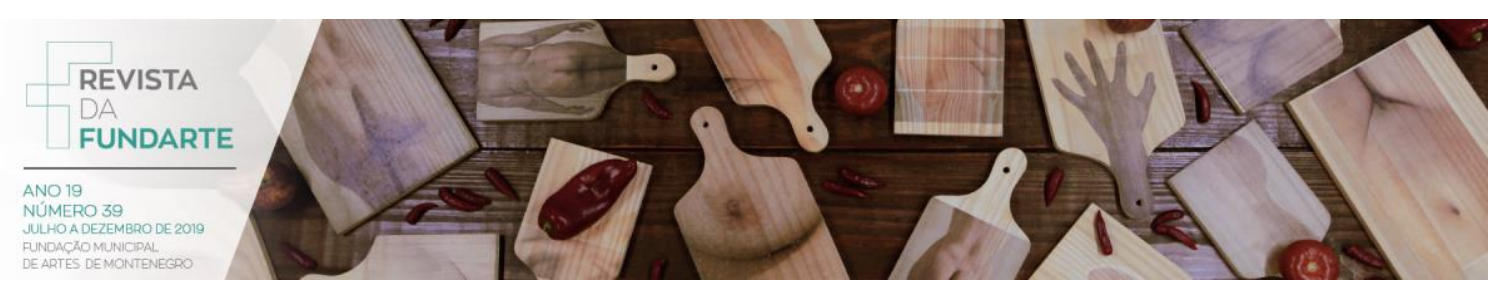

Assim, as fotografias produziram forte impacto nas iconografias do século XIX, e, mais ainda, na contemporaneidade, onde a grande mudança se apresenta na produção dessas imagens. Como esclarece Julio Plaza "Isso se deve à mudança radical de sistemas produtivos, não mais o domínio de sistemas artesanais ou mecânicos, mas sim de sistemas eletrônicos que transmutam as formas de criação, geração, transmissão, conservação e percepção de imagens”. (PLAZA, 1993, p. 72)

O material escolhido para este trabalho constitui-se de fotos e vídeos pessoais, salvos no meu aparelho celular durante o ano de 2017. Esse fenômeno de recebimento, armazenamento e compartilhamento de imagens, embora aqui tratado como caso isolado, parece fazer parte de uma prática contemporânea. Segundo Venturelli (2004, p. 85) "O homem contemporâneo urbano vive submerso por uma proliferação incontrolável de imagens. Vive-se numa imensa imagoteca universal, proporcionada principalmente pelos meios de comunicação". A ideia de realizar a exposição de uma videoinstalação numa cabine fechada, em que as imagens em movimento ocupam todas as paredes, vai ao encontro dessa proliferação e desse sufocamento.

As imagens recebidas e enviadas pelos dispositivos móveis parecem buscar comunicação entre os pares e grupos, reafirmar posicionamentos, confirmar experiências, garantir a "boa" passagem do tempo, o aproveitamento e a particular maneira de viver a vida. Para Flusser (2007), a explicação está na incapacidade do ser humano em lidar com a morte e a solidão.

A comunicação humana é um artifício cuja intenção é nos fazer esquecer a brutal falta de sentido de uma vida condenada à morte. Sob a perspectiva da "natureza", o homem é um animal solitário que sabe que vai morrer e que na hora da sua morte está sozinho. Cada um tem de morrer sozinho por si mesmo. E, potencialmente, cada hora é a hora da morte. Sem dúvida não é possível viver com esse conhecimento da solidão fundamental e sem sentido. A comunicação humana tece o véu do mundo codificado, o véu da arte, da ciência, da filosofia e da religião, ao redor de nós, e o tece com pontos cada vez mais apertados, para que esqueçamos nossa própria solidão e nossa morte, e também a morte daqueles que amamos. Em suma, o homem comunica-se com os outros; é um "animal político", não pelo fato de ser um animal social, mas sim porque é um animal solitário, incapaz de viver na solidão. (FLUSSER, 2007, p. 90 e 91).

VALANDRO, Charmeni Vargas. Narrativas e excesso: relações das imagens ubíquas. Revista da FUNDARTE, Montenegro, p. 48-68, ano 19, oㅜ 39, julho/dezembro de 2019.

Disponível em: http://.seer.fundarte.rs.gov.br/index.php/RevistadaFundarte/index $>20$ de dezembro de 2019. 


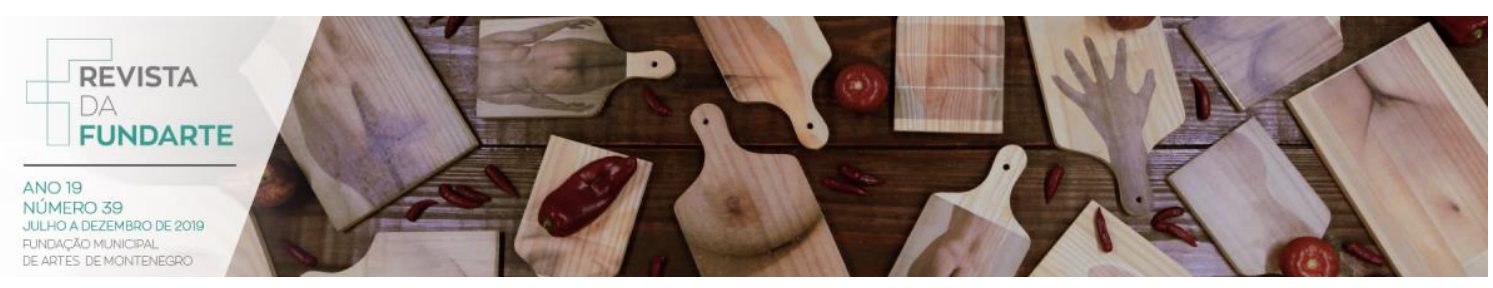

E essa comunicação humana se dá no estabelecimento de um mundo codificado, ou seja, um mundo possível pelos símbolos ordenados, no qual se represam as informações adquiridas. No processo de produção de novos conhecimentos, os seres humanos trocam diferentes informações na esperança de sintetizar uma nova; para manter as informações, eles as compartilham na esperança de resistir melhor ao efeito entrópico da natureza. (FLUSSER, 2007)

As imagens e vídeos utilizados nesta videoinstalação em sua maioria foram recebidos e enviados através do aplicativo Whatsapp ${ }^{5}$, mas há também arquivos íntimos que nunca foram compartilhados. No entanto, registros banais, advindos de grupos, distribuídos em massa, estão localizados juntamente com imagens e vídeos particulares, produzidos cuidadosamente em prol de assuntos que me são caros. Desta forma, toda a gama arquivada no dispositivo se torna banal pelo excesso e indefinição ou aglomeração. A ressignificação de tais arquivos, em uma videoinstalação, propõe uma transcodificação, conforme esclarece Flusser (2011, p. 73), "A cada vez que troca de canal, a fotografia muda de significado: de científica passa a ser política, artística, privativa. A divisão das fotografias em canais de distribuição não é operação meramente mecânica: trata-se de operação de transcodificação". Dessa forma, os arquivos que ora podem ser íntimos ou de cunho comunicacional, ao serem expandidos pelas telas das televisões e enclausurados na cabine da instalação, se transcodificam numa ressignificação, que opera à luz do excesso, tencionando uma possível lógica da memória, da máquina e do ser.

Amalgamar comunicação de massa num trabalho artístico requer 0 entendimento de que não há natureza própria das imagens da arte; também, de que o contexto histórico e cultural e em que o artista está reflete diretamente na produção da obra. Sendo assim, a forma como me comunico, como utilizo a tecnologia e as mídias, como aponto meu olhar e minha crítica para as imagens e o seu consumo, se faz numa re-apresentação (sic) mais voltada para a seleção e exibição, identificados como processo e desenvolvimento da obra, que para a criação de um objeto novo. Nesse sentido, "O trabalho da arte é, portanto, jogar com

5 Whatsapp é um aplicativo para smartphones utilizado para troca de mensagens de texto instantaneamente, além de vídeos, fotos e áudios através de conexão de internet.

VALANDRO, Charmeni Vargas. Narrativas e excesso: relações das imagens ubíquas. Revista da FUNDARTE, Montenegro, p. 48-68, ano 19, ํo 39, julho/dezembro de 2019.

Disponível em: http://.seer.fundarte.rs.gov.br/index.php/RevistadaFundarte/index $>20$ de dezembro de 2019. 


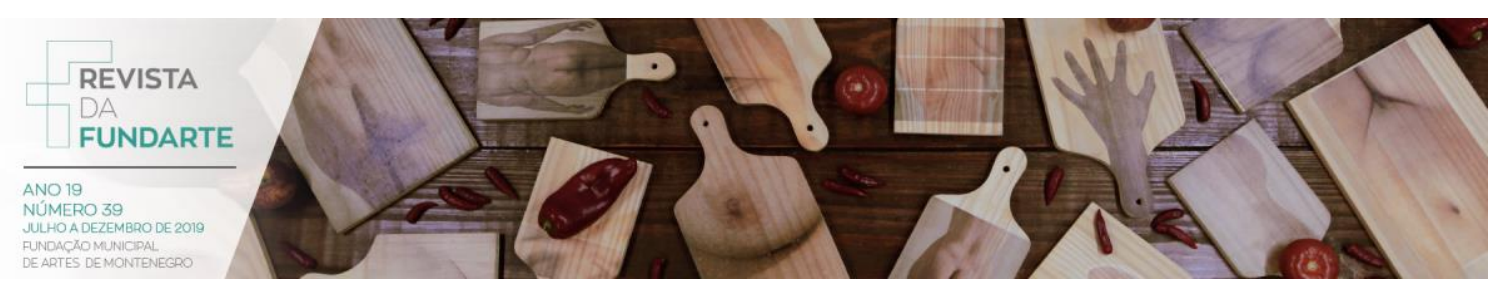

a ambiguidade das semelhanças e a instabilidade das dessemelhanças, operar uma redisposição local, um rearranjo singular das imagens circulantes". (RANCIÈRE, 2012, p. 34) A criação, neste caso, é a reordenação de arquivos já existentes numa reconfiguração e montagem de fotografias, vídeos e gifs ${ }^{6}$, que serão expandidos para telas maiores, multiplicados e exibidos em sequência no interior de uma cabine.

Graças às tecnologias ubíquas e móveis, as pessoas podem estar conectadas o tempo todo em ambientes digitais (DOMINGUES, 2009) e, assim, trocar informações, receitas de bolo, imagens de roupas, de documentos, de nuvens, de sapatos, de pessoas, de cabelos, de lição da faculdade, de castelo de brinquedo, de obras de arte.... Desta forma, tais imagens estabelecem novos modelos operativos no sistema de comunicação, pois são imagens-linguagens. Como aponta Julio Plaza (1993, p. 83): "O tráfico entre o verbal (sintagmático) e o não verbal (paradigmático) encontra aqui seu lugar como extensão do caráter intersemiótico do pensamento, pois este atua por imagens, diagramas e metáforas, além de palavras". As novas mídias são, de certa maneira, novas linguagens. As codificações de experiências, nos dias de hoje, se tornam mais visuais que textuais. Embora as imagens digitais tenham sua origem e estrutura nos códigos binários que são nada mais que informações textuais transformadas por sistemas em pixels formadores das imagens, "A imagem digital se apresenta como uma matriz de números em filas e colunas, na memória do computador". (PLAZA, 1993, p.73). Transparece aqui o paradoxo textual-imagético dos arquivos deste trabalho.

Conforme aponta Plaza, (1993, p. 73) "O encontro da informática com os sistemas de representação visual promove uma troca cultural no que se refere à construção, veiculação e visualização das imagens". Neste caso não há mais distinção entre o emissor e o receptor, a interatividade entre ser humano e máquina ocorre na forma falada, escrita, gráfica e visual. Porém, este mesmo mecanismo faz com que o suporte da imagem se dissolva, porque os arquivos se transmutam em diversos meios. Contradizendo a projeção de McLuhan de que os meios seriam as mensagens, pois “... não existe mais meio, somente trânsito de informações entre

\footnotetext{
${ }^{6}$ GIF (Graphics Interchange Format ou formato de intercâmbio de gráficos) é um formato de imagem muito usado na Internet de tamanho compacto.
}

VALANDRO, Charmeni Vargas. Narrativas e excesso: relações das imagens ubíquas. Revista da FUNDARTE, Montenegro, p. 48-68, ano 19, no 39, julho/dezembro de 2019.

Disponível em: http://seer.fundarte.rs.gov.br/index.php/RevistadaFundarte/index $>20$ de dezembro de 2019. 


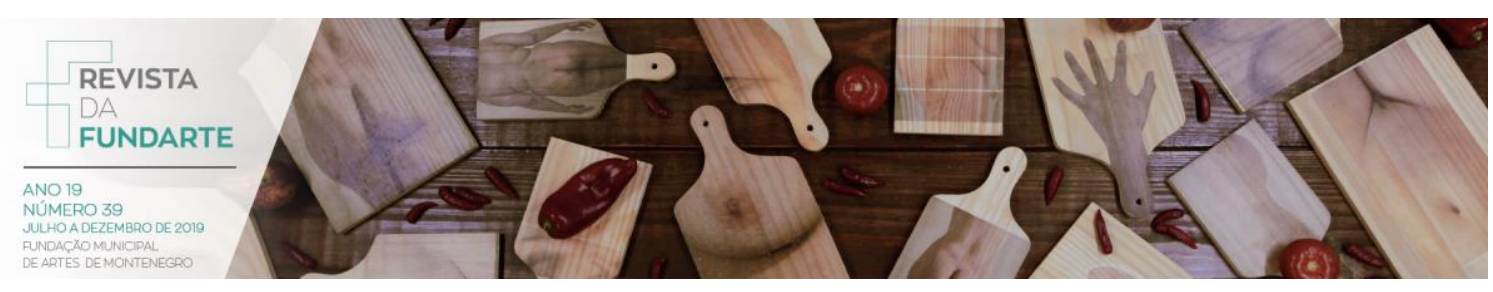

suporte, interfaces, conceitos e modelos como meras matrizes numéricas". (PLAZA, 1993, p. 75), o fluxo das imagens digitais se transforma instantaneamente em memória capaz de ser infinitamente retornado e transformado, num ciclo sem fim: a obra passa a ser o processo e não o objeto e seus meios.

Muito além das questões de autenticidade, abordadas por Benjamin, as obras de arte que utilizam as mídias atuais trazem também à tona discussões quanto obsolescência e efemeridade, pois desde a criação dos computadores e das novas tecnologias, muitos suportes ficaram obsoletos em pouco tempo, como os disquetes e outros. Assim nada garante que a obra atual, instaurada pelo meio tecnológico vigente, poderá ser revista num futuro próximo. Conforme corrobora Plaza (1993, p. 75 e 76$)$ :

As tecnologias informáticas da imagem tornam possível a produção potencial quase infinita de imagens, sem que nenhuma delas exista como tal. É aqui onde se manifesta precisamente a natureza da imagem como acontecimento, ou seja, o movimento fluido de uma aparição/desaparição que permite qualificar este processo de espectral e imaterial, pois o acesso à totalidade da imagem é impossível devido à sua segmentação.

De qualquer forma, as imagens utilizadas nesta videoinstalação, quer em movimento ou não, são possíveis graças à tecnologia digital que proporciona a produção e o armazenamento das mesmas, são abundantes graças à mídia eletrônica que permite o compartilhamento e recebimento dessas imagens e assim viabiliza um sistema de comunicação visual entre os pares ou grupos.

Diante deste excesso de imagens identificado na memória do dispositivo, perante o aumento constante destes arquivos, a propagação exponencial diária a que estamos submetidos, me vi questionando o sentido, a importância e a banalização de tais imagens. Senti a obrigação de olhar para elas, desmembrá-las, reagrupá-las e ressignificá-las. Como graduada em Publicidade e Propaganda e com uma visão crítica a esse consumo exacerbado de imagens e seus signos, me vi submersa em minhas próprias imagens, refletindo um padrão que me parece contemplado pela comunicação de massa e legitimado pelas mídias.

Os acontecimentos e ações parecem pretexto para a imagem, onde a finalidade passa a ser o registro e o compartilhamento do que foi vivido, a 2019. 


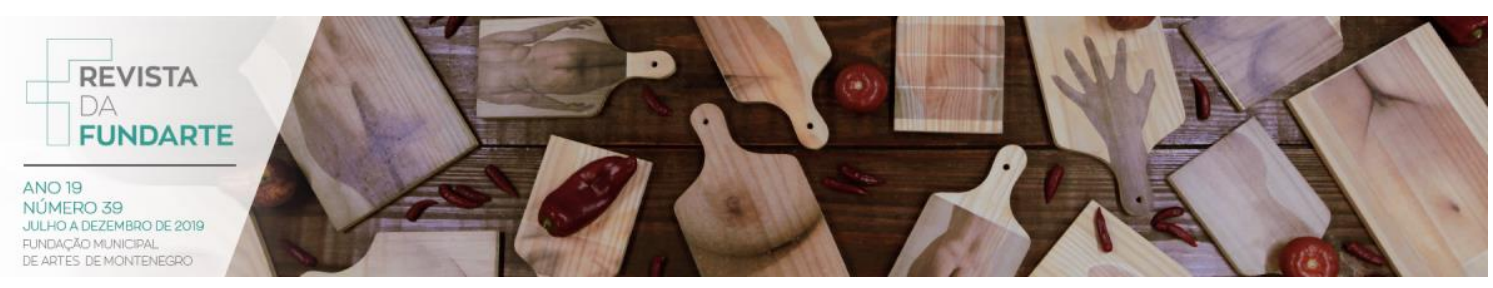

representação passa a ser mais importante que a experiência. Para Debord (2003, p. 14) "A realidade considerada parcialmente reflete em sua própria unidade geral um pseudo mundo à parte, objeto de pura contemplação". O espetáculo não consiste apenas num conjunto de imagens, mas na relação social entre as pessoas, mediada por essas imagens.

Talvez o papel de mediação das imagens tenha conexão com a mudança da nossa relação com o tempo, que passou de cíclico, na era medieval, para irreversível da produção, ditado pelas mercadorias, na modernidade, como defende Guy Debord (2013) em "A Sociedade do Espetáculo " “... o tempo que se afirma oficialmente em toda a extensão do mundo como o tempo geral da sociedade, não significa mais do que interesses especializados que o constituem, não é senão um tempo particular". (2003, p. 120) A representação do tempo consumível, no qual as imagens se proliferam e se reafirmam, e um tempo de consumo de imagens, onde elas encontram a realimentação, não passa de uma imensa acumulação de espetáculos. "A realidade do tempo foi substituída pela publicidade do tempo" (DEBORD, 2003, p. 125) e talvez essa mudança conceitual nos dê indícios das mudanças comportamentais atuais referente às imagens e suas linguagens.

No vídeo "Mobile phones have killed photography" (Telefones móveis mataram a fotografia), realizado pela BBC News, o diretor de vídeo e fotografia Wim Wenders traz a questão das fotografias produzidas pelos aparelhos celulares e questiona o que são e como poderiam ser chamadas tais imagens, já que, do seu ponto de vista, elas não são fotografias, pois nem mesmo os produtores olham para elas nas pastas dos dispositivos móveis, elas não são impressas, não mais retratam a realidade e não servem para explorar a criatividade. O diretor diz que nunca a fotografia esteve tão viva e em todos os lugares e nunca esteve tão morta. A fala de Wim Wenders nos faz refletir sobre o papel simbólico das fotografias, sobre a banalização e o excesso, a efemeridade e o trivial, mas também pode nos fazer pensar a respeito das facilidades incorporadas a essa nova modalidade comunicacional, fato que ele não nega, mas apenas sugere uma separação linguística entre o fenômeno contemporâneo das fotografias em aparelhos celulares

7 Disponível em: https://www.youtube.com/watch?v=9ezzpuOqkX4\&t=9s FUNDARTE, Montenegro, p. 48-68, ano 19, oㅜ 39, julho/dezembro de 2019.

Disponível em: http://.seer.fundarte.rs.gov.br/index.php/RevistadaFundarte/index $>20$ de dezembro de 2019. 


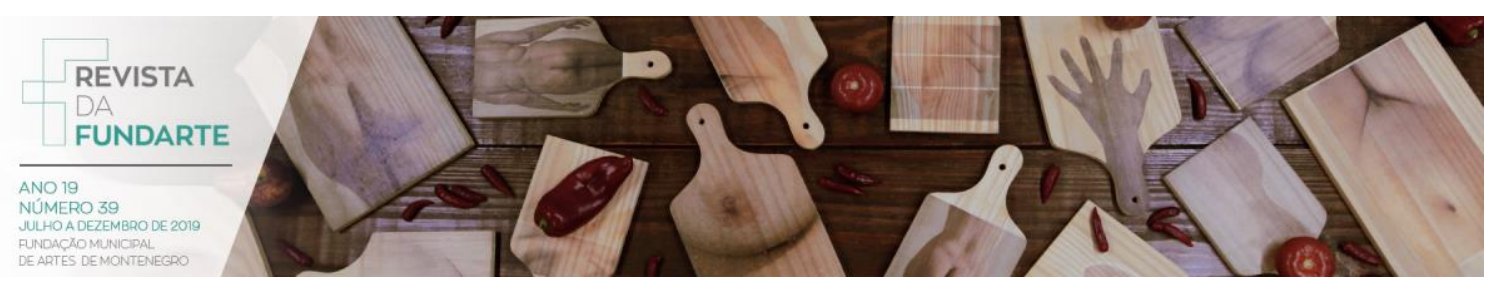

e a tradicional fotografia realizada em aparelhos fotográficos analógicos e digitais por profissionais ou amadores. Essa separação linguística, assim como as reflexões sobre o tema, também são abordadas pelo autor Joan Fontcuberta, pelo que ele chama de pós-fotografia. Para Fontcuberta é "a fotografia adaptada à nossa vida online" (FONTCUBERTA, 2011), o autor problematiza o processo e o acesso à fotografia, que vai além do resultado, mas que se expressa nos números, no armazenamento e na efemeridade das produções contemporâneas.

A partir do entendimento deste fenômeno no comportamento cotidiano, passo a questionar que imagens são essas e o que elas podem me indicar sobre arquivamentos e memórias particulares ou coletivas.

\section{IMAGENS, MEMÓRIA E ARQUIVAMENTO}

Meu ano de 2017 em imagens e movimento:

O que vivi? Como me relacionei?

Quantas amizades fiz, refiz, desfiz?

Que lugares passei?

Quantos abraços dei?

Quantas vezes me embriaguei?

Quantas músicas dancei?

Quantas vezes chorei?

Tive medo? Desisti?

Quantas vezes me apaixonei?

Me decepcionei?

Sorri? Ri? Feri?

O quanto de minha vida cabe no bolso? Que memória é essa que se reproduz numa cabine, onde compartilho e me permito vulnerável? Me desnudo, me exponho, me desarmo? 


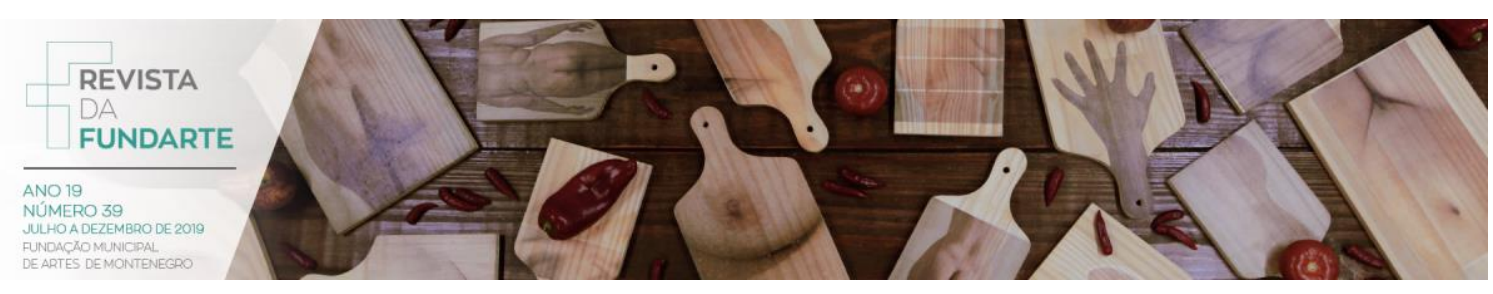

Que memória é essa que fala de mim sem eu? Que aponta o meu olhar como um guia? Que recebe, aceita e guarda? E o que dessa memória fica?

A subjetividade da vida é passível de ser quantificada e qualificada por meio destes arquivos?

Segundo Priscila Arantes (2015, p.172) "A necessidade do registro parece aumentar graças a um renovado e insaciável desejo de autoexibição e colecionismo". Como já foi visto anteriormente, as mídias e a tecnologia parecem ter um papel importante nesta prática contemporânea, facilitando o processo de arquivamento e memória, que vêm imbricadas no fazer fotográfico e videográfico do aparelho celular.

Buscar todas as imagens e vídeos da memória do aparelho celular, durante 0 período de um ano, a fim de ressignificá-las, aponta meu olhar para 2017 enquanto tempo vivido, para cada imagem específica e minha intimidade com elas, resgata as ações, emoções e sentimentos do que passou sob uma nova perspectiva, pois, com a passagem do tempo, alterações subjetivas e cognitivas acontecem com o ser humano. O que transforma o fazer em um processo aberto de criação de uma poética visual e sensorial que está em constante desenvolvimento.

A produção e armazenamento das imagens podem estar relacionados a um processo de se reconhecer no tempo, nas ações, na criação de um significado para a existência. Fontcuberta diz que,

Tanto a nossa noção do real quanto a essência de nossa identidade individual dependem da memória. Não somos nada além da memória. A fotografia, portanto, é uma atividade fundamental para nos definir, que abre uma dupla via de ascese para a autoafirmação e para o conhecimento. (FONTCUBERTA, 2010, p.38).

A identidade do sujeito pode ser construída assim, no cenário contemporâneo, por meio de discursos gerados pela linguagem fotográfica e audiovisual, resultante da relação entre as tecnologias, mídias eletrônicas e a cultura visual. Segundo Flusser (2007, p. 87): “Construímos arquivos de nós mesmos, e, por conseguinte reproduzimo-nos nos arquivos, diante da necessidade de permanecermos na memória do mundo". Dessa forma, recordação biológica e 


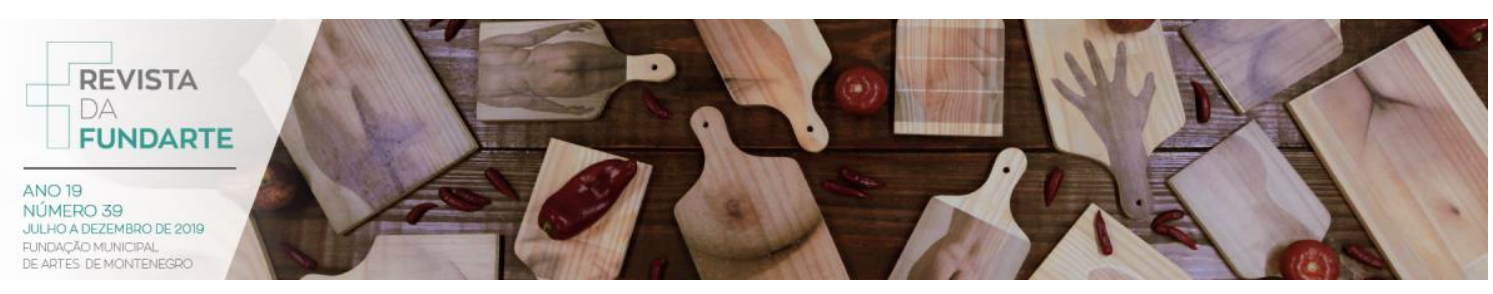

tecnológica se misturam no processo de organização, identificação e estruturação do pensamento e dos acontecimentos passados com vistas ao planejamento do futuro.

Condição básica da humanidade, a memória é responsável pelo encadeamento dos fatos e por garantir que tudo não passe de períodos momentâneos desconectados. "Por memória se entende um princípio de conservação do passado, que não é aquilo que passou ou desapareceu, mas, ao contrário, o que se conserva". (ARANTES, 2015, p. 57) A memória pode ser revisitada e rearranjada, enquanto informação disponível, conforme as associações que indivíduo for capaz de desenvolver. Sendo assim, ela não é um bloco fechado contendo a verdade absoluta do que se passou, mas as conexões que foram feitas sobre o que aconteceu. Nesse sentido, Priscila Arantes aponta para a questão das narrativas possíveis numa época em que o colecionismo de informações e de dados se faz presente, indicando a importância da criação de links entre as informações disponíveis e o desdobramento em múltiplas narrativas. E ainda sugere que "o banco de dados não é somente o conjunto de materiais armazenados, mas também o sistema que guarda as informações de uma determinada forma" (ARANTES, 2015, p. 69).

Assim como a natureza do sistema diz respeito às informações contidas nele, também o processo e as instituições ou pessoas que possuem o banco de dados têm influência nesses arquivos. "O arquivo seria uma noção abstrata do conjunto de regras de um sistema discursivo de uma determinada época, e não a noção corrente cuja matéria resume-se aos escritos que documentam ou testemunham o passado, guardado e imóvel" (ARANTES, 2015 p. 91).

No caso dos arquivos utilizados nesta videoinstalação, que foram produzidos, recebidos ou enviados através do dispositivo móvel, há parcialidade de minha parte, pois os arquivos passaram por uma seleção, um julgamento e então um arquivamento, ou mesmo um esquecimento na memória do aparelho. Conclui-se que eles dizem respeito à minha vida, no período de um ano, sendo este registro não um catálogo de ações e fatos cronológicos, mas que fazem parte da construção FUNDARTE, Montenegro, p. 48-68, ano 19, ํo 39, julho/dezembro de 2019.

Disponível em: http://.seer.fundarte.rs.gov.br/index.php/RevistadaFundarte/index $>20$ de dezembro de 2019. 


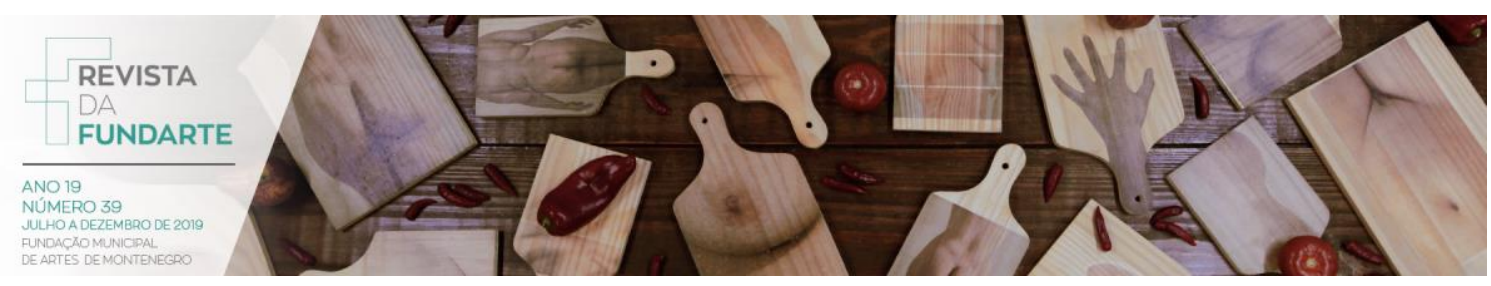

do discurso vigente num processo sempre aberto, pois as relações subjetivas que eles proporcionam mudam conforme meu pensamento e minhas atitudes.

\section{O PROCESSO}

A construção da videoinstalação proposta neste trabalho engloba tanto a produção de quatro vídeos quanto a sua exposição numa cabine de 1,20m x 1,20m (figuras 2 e 3). O material utilizado para a construção de tais vídeos é o montante de arquivos que foram identificados na memória do meu smartphone, relativos ao ano de 2017. Optei por esse período por se tratar de arquivos dos quais eu já tinha um certo distanciamento, em função do tempo.

Baixei todas essas imagens, em movimento ou não, no computador e para cada um designei uma pasta referente ao mês correspondente. Assim, no programa Adobe Premier comecei a ancoragem de um arquivo no outro, pela ordem de data. Fiz o primeiro vídeo de janeiro a março e os seguintes também de períodos trimestrais. Decidi não manipular as imagens esteticamente e nem descartar nenhuma delas para que se mantivesse a integridade do banco de dados.

Posteriormente, temporizei as imagens em 01' e deixei os vídeos integrais, redimensionei todos os arquivos para que eles ocupassem o espaço total da tela e salvei cada vídeo em um pendrive.

A construção da cabine será feita com chapas de MDF 18mm pretas, uma abertura de entrada, fechadura e suportes para as televisões. Em cada parede da estrutura será pendurada uma televisão de 42" com entrada para pendrive em que os vídeos rodam concomitantemente em looping.

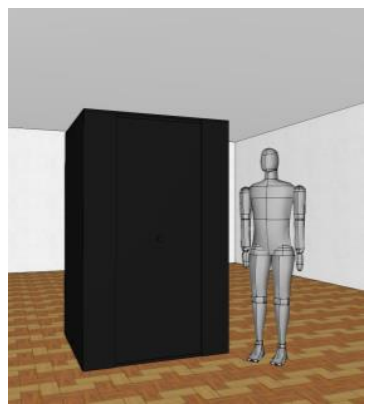

Figura 2: Projeto da parte externa da cabine.

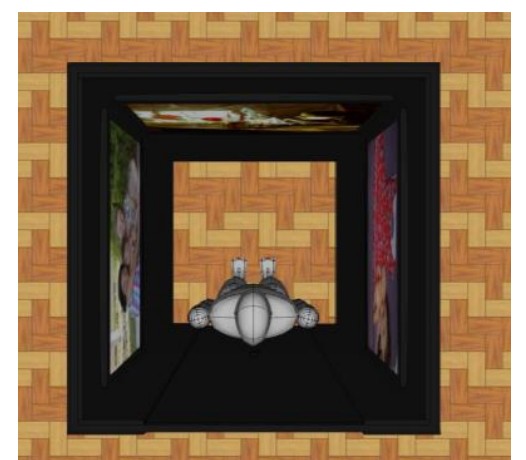

Figura 3: Projeto da parte interna da cabine. 


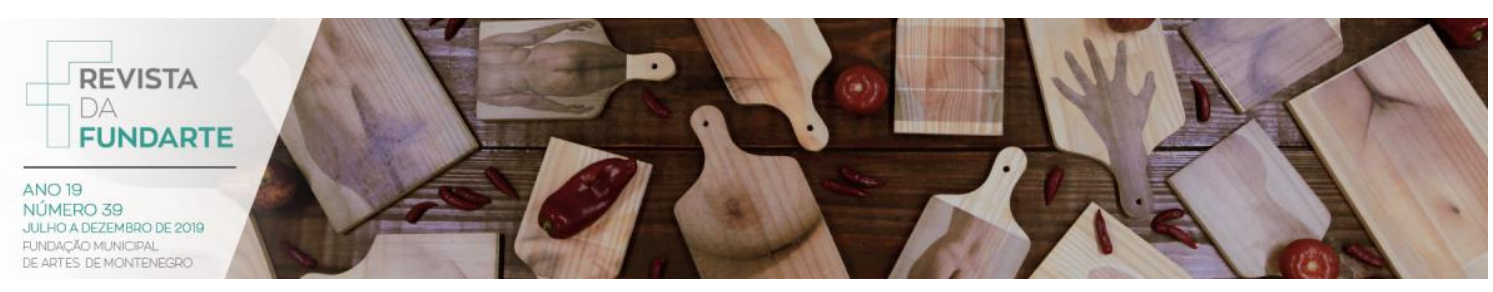

O processo de criação da videoinstalação se deu de maneira bem particular e fragmentada, entre busca por conhecimento técnico que fosse capaz de satisfazer minhas necessidades estéticas, aparatos eletrônicos e construção física do objeto da instalação. Segundo Rey (2002, p. 126) "É nessa borda, entre procedimentos diversos transpassados, por significações em formação e deslocamentos, que se instaura a pesquisa". Tal pesquisa de formato descritivo/analítico tem embasamento nas leituras bibliográficas do referencial teórico e artístico e andou em paralelo à criação artística que culmina com a videoinstalação. Assim, como explica Lancri (2002, p. 19), "Um pesquisador em artes plásticas, com efeito, opera sempre, por assim dizer, entre conceitual e sensível, entre teoria e prática, entre razão e sonho". Diferentemente das pesquisas em outras áreas das Ciências Humanas, na pesquisa em artes a criação artística se constrói simultaneamente a elaboração metodológica. Desta forma há uma dupla influência na produção da poética, as leituras bibliográficas e o embasamento artístico advindo do Sistema das Artes direcionam a produção, da mesma forma que a criação aponta para novos autores e artistas. Há uma retroalimentação poética e poiética ${ }^{8}$ na construção da obra-pesquisa.

Acredito ser importante sinalizar ainda que a pesquisa está ocorrendo enquanto projeto de videoinstalação, que foi testado na Universidade Feevale e em minha casa em condições diversas da projetada para a obra final, pois a cabine ainda não foi produzida, então percebo que meu texto poderá ter lacunas que serão preenchidas na instauração da obra, no dia da banca.

\section{PERCEPÇÕES}

Identifiquei, com esta videoinstalação, a familiaridade que tenho com as imagens que, embora em número muito maior que os vídeos, são seguidamente manipuladas na memória do aparelho e essa familiaridade se reafirma pela troca entre uma e outra, na produção do vídeo, que repete a forma com que passamos as

\footnotetext{
${ }^{8}$ Poiética diz respeito a reflexão sobre o processo de criação da obra, segundo René Passeron (1997).
} 


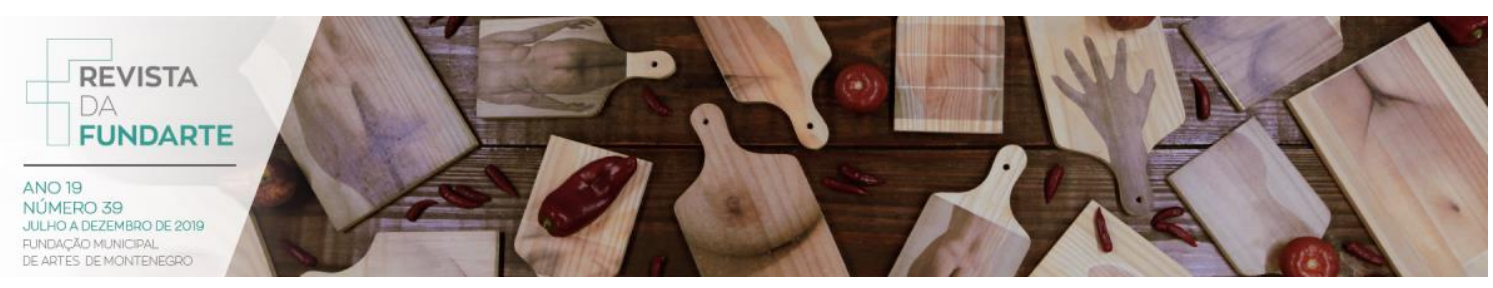

imagens no dispositivo móvel, deslizando-as para o lado. Esse formato rápido de manipulação é habitual no âmbito individual de utilização do aparelho celular.

Já os vídeos, que rodaram de forma integral na cabine, trouxeram o incômodo da novidade e do imprevisto, pois percebi que não tinha conhecimento da existência de alguns, assim como não havia visualizado integralmente quase nenhum, e o que lembrava de vários daqueles vídeos era simplesmente o frame inicial, que por sua vez me remetiam a algum tema.

Percebi que o tempo de fruição desses arquivos é distinto e que suas linguagens são diversas. Enquanto as imagens são dinâmicas e podem ser facilmente manipuladas, enviadas, compartilhadas, excluídas e modificadas, alguns de meus vídeos são registros de momentos que nunca foram revistos, e são arquivos que tiveram sua motivação no ensejo, mas que não mereceram replay, pois não sendo possível acelerar a exibição, como no caso das fotografias, tornaram-se anacrônicos.

Outra percepção quanto as diferenças entre os arquivos é a espontaneidade identificada nos vídeos. Conforme aponta Sarzi-Ribeiro sobre os processos e procedimentos técnicos das artes:

Essas linguagens atuam na construção da expressão plástica dos textos visuais e audiovisuais como a pose, a encenação, o plano aproximado, a montagem, a maquiagem e os artifícios visuais e sonoros, e/ou pelo contrário, a filmagem do corpo em seu estado natural e espontâneo em registros de ações cotidianas. (SARZI-RIBEIRO, 2016, p. 47).

Os apontamentos da autora foram identificados na construção e visualização deste trabalho, pois os vídeos permitem acompanhar um momento real, uma sequência de movimentos, de atitude, de fala e de vida menos encenado que usualmente nas fotografias. Assim, noto que as linguagens diferem tanto na produção quanto na finalidade e percebo que o interessante não é a especificidade de cada linguagem, mas a interseção entre elas, como bem apontou Priscila Arantes (2015).

$\mathrm{Na}$ videoinstalação, em que ocorre tudo ao mesmo tempo, em quatro monitores, temos ainda a questão sonora que dialoga com as imagens, a FUNDARTE, Montenegro, p. 48-68, ano 19, ํㅜ 39, julho/dezembro de 2019.

Disponível em: http://.seer.fundarte.rs.gov.br/index.php/RevistadaFundarte/index $>20$ de dezembro de 2019. 


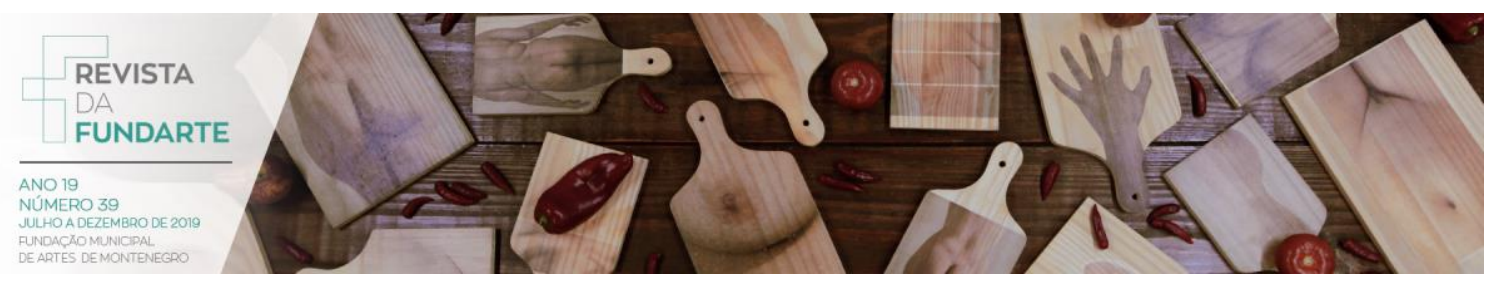

sobreposição dos ruídos que intensifica o bombardeio de informações. Somos literalmente encurralados pelo frenesi das imagens, movimentos e sons, sem que tenhamos controle ou ponto de fuga. É a vida midiática e particular de um ano condensada numa cabine.

Relaciono este trabalho com duas obras distintas de artistas brasileiros. $O$ primeiro é uma instalação de Cildo Meireles, intitulada Babel (2001-2006) (Figuras 4 e 5), em que ele empilha mais de 900 rádios em uma torre de 5 metros de altura e 3 metros de diâmetro. Cada aparelho está sintonizado em uma frequência diferente e, ao se aproximar da obra, o espectador percebe a confusão dos sons diversos, 0 caos então ganha força e forma. Numa outra perspectiva, também sugiro caos ao passar os vídeos concomitantes, porém aponto para arquivos imagéticos e pessoais.

A segunda obra é da artista gaúcha Elaine Tedesco e faz parte do projeto Cabines para o Isolamento e Camas Públicas (2002) (Figura 6), em que ela distribui cabines em locais públicos e proporciona ao espectador um local de refúgio com características de confinamento e isolamento. Há várias semelhanças físicas em minha instalação com as cabines da professora Elaine, porém eu proporciono um bombardeio imagético, uma imersão em meus arquivos, ao contrário do refúgio, reforço a presença externa no interior da cabine.
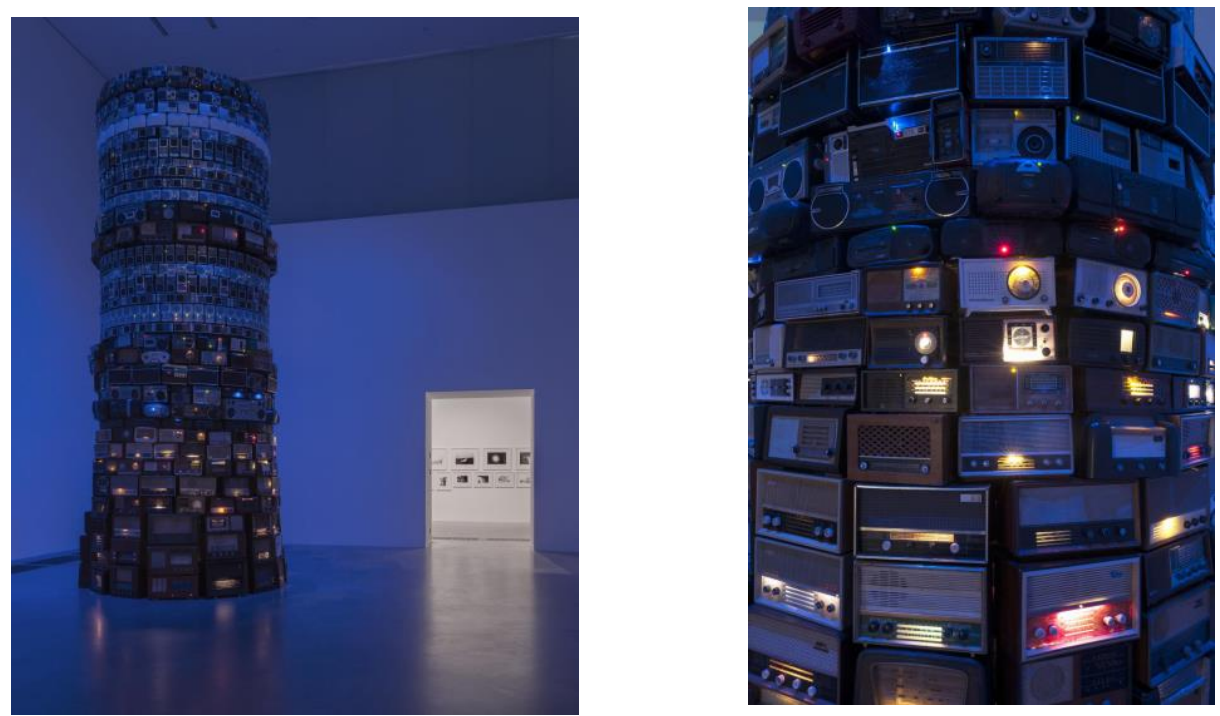

Figuras 4 e 5: Babel, 2001-2006, Cildo Meireles Fonte: https://www.tate.org.uk/art/artworks/meireles-babel-t14041 FUNDARTE, Montenegro, p. 48-68, ano 19, no 39, julho/dezembro de 2019.

Disponível em: http://.seer.fundarte.rs.gov.br/index.php/RevistadaFundarte/index $>20$ de dezembro de 2019. 

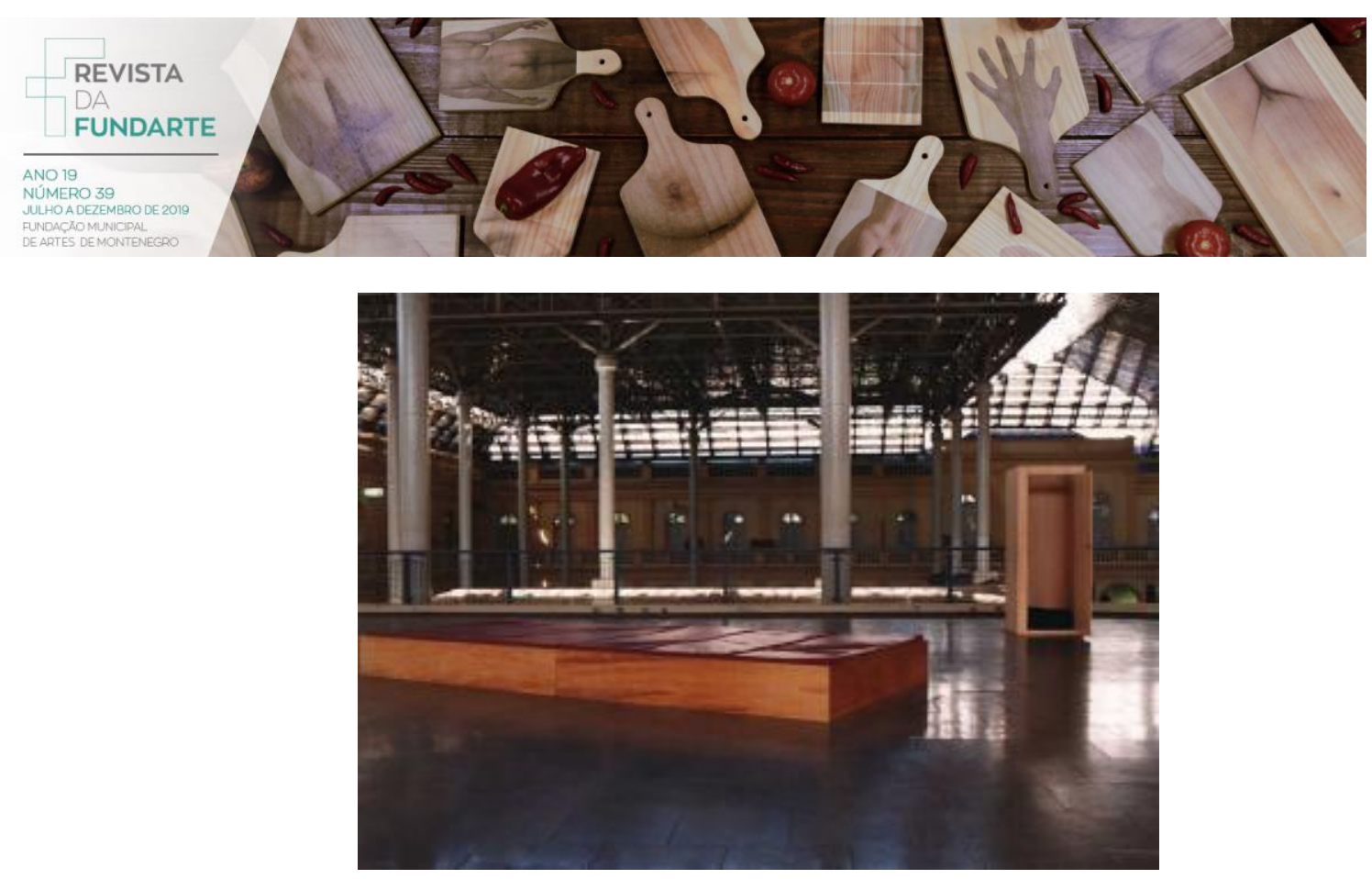

Figura 6: Cabines para o Isolamento (2002), Elaine Tedesco. Fonte: http://comum.com/elainetedesco/index2.htm

\section{CONSIDERAÇÕES FINAIS}

Percebo com este trabalho, a influência dos meios de comunicação, da tecnologia e das mídias no comportamento contemporâneo e sendo assim, na vida e na arte. Aproximei comunicação de massa e arquivos pessoais, por meio do processo de desenvolvimento dos vídeos, em interseção de suas linguagens distintas, suas estruturas e finalidades, compreendendo o fazer artístico desde o primeiro indício de potencial identificado num material ou projeto, até a exposição final do trabalho. Assim, cada disciplina da Especialização em Poéticas Visuais, reverberou na construção conceitual e artística deste projeto. A pesquisa, assim como a capacidade criativa e produtiva, proporciona um trabalho que tende a escapar da superfície, aprofundando questões contemporâneas sobre excessos, narrativas, imagem e ubiquidade.

Esta videoinstalação foi possível pelos aparatos tecnológicos, mas essa relação é ambivalente, pois assim como a tecnologia facilita o processo de construção da obra, também põe em risco sua manutenção e conservação. Desta forma, sinto que, tanto a obra, quanto os arquivos pessoais são suscetíveis à novas descobertas e suas aplicabilidades.

Quanto a apreciação da obra, me afasto de possíveis interpretações, pois a arte tem um caráter múltiplo e pessoal de observações e perspectivas. $\mathrm{O}$ objetivo 


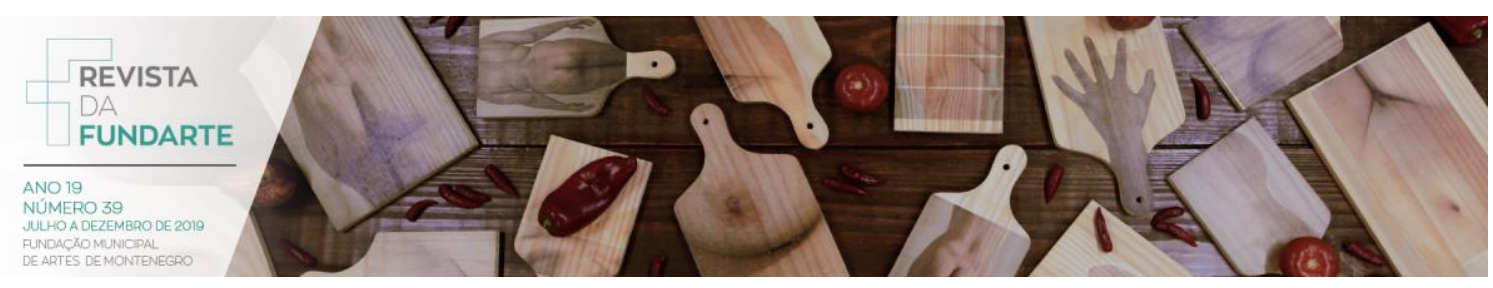

aqui foi a ressignificação dos arquivos pessoais sob o viés da comunicação, memória e arquivamento. Como possíveis desdobramentos penso na alternativa de um programa em que o espectador possa conectar o seu aparelho, garantindo uma interatividade maior com a obra. Outra possibilidade é uma exposição em que tenha várias cabines e cada uma delas tenha arquivos distintos resgatados da memória do aparelho celular, como uma cabine em que só os áudios sejam utilizados, outro apenas com gifs, outro com fotografias e um último com vídeos ou o que mais vier do cenário midiático comunicacional, explorando assim, as linguagens separadamente e as relações com a arte e a vida contemporânea.

\section{Referências:}

ARANTES, Priscila. Artes e mídia no Brasil: perspectivas da estética digital. Revista ARS, São Paulo, v. 3, n. 6, p. 52-65, jan. 2005.

ARANTES, Priscila. Re/escrituras da arte contemporânea: história, arquivo e mídia. Porto Alegre: Sulina, 2015.

DEBORD, Guy. A sociedade do espetáculo. 2003. Editoração, tradução do prefácio e versão para eBook: eBooksBrasil.com/projetoperiferia.

Disponível em: <http://www.ebooksbrasil.com/eLibris/socespetaculo.html> Acesso em: 18 abril 2018.

DOMINGUES, Diana (org.). Arte e vida no século XXI: tecnologia, ciência e criatividade. São Paulo: Editora UNESP, 2003.

DOMINGUES, Diana, SARETTA, Flávia Gisele et al., tradutores. Arte, ciência e tecnologia: passado, presente e desafios. São Paulo: Editora UNESP, 2009.

FLUSSER, Vilém. Filosofia da caixa preta: ensaios para uma futura filosofia da fotografia. São Paulo: Annablume, 2011.

FLUSSER, Vilém. O mundo codificado por uma filosofia do design e da comunicação. Tradução: Raquel Abi-Sâmara. São Paulo: Cosac Naify, 2007.

FONTCUBERTA, Joan. O beijo de Judas: fotografia e verdade. Tradução: Maria Alzira Brum Lemos, Editorial Gustavo Gili, SL, Barcelona, 2010. 


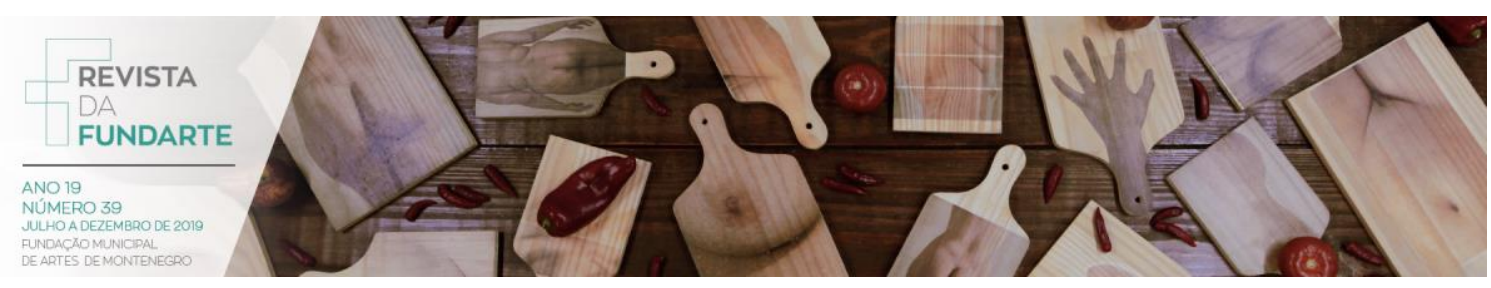

FONTCUBERTA, Joan. Por um manifesto pós-fotográfico. Tradução de Gabriel Pereira 2011. Studium, Campinas, n. 36, 2011. Disponível em: http://www.studium.iar.unicamp.br/36/7/>.Acesso em: 15 jan 2019.

LANCRI. Jean. Colóquio sobre a metodologia em artes plásticas na universidade. In: BRITES, Blanca; TESSLER, Elida (org.) O meio como ponto zero - Metodologia da pesquisa em artes plásticas. Porto Alegre: UFRGS, 2002. P. 17-34.

MELLO, Christine. Extremidades do vídeo. Conexão - Comunicação e Cultura, Caxias do Sul, v.3, n. 6, p. 17-34, 2004.

PLAZA, Julio. As imagens de terceira geração, tecnopoéticas. In: PARENTE, André (org.) Imagem-máquina: a era das tecnologias do virtual. Rio de Janeiro: Ed. 34, 1993.

RANCIÈRE, Jacques. O destino das imagens. Tradução: Monica Costa Netto. Organização: Tadeu Capistrano. Rio de Janeiro: Contraponto, 2012.

REY, Sandra. Por uma abordagem metodológica da pesquisa em artes. In: BRITES, Blanca; TESSLER, Elida (org.) O meio como ponto zero - Metodologia da pesquisa em artes plásticas. Porto Alegre: UFRGS, 2002. P. 124-140.

RUSH, Michael. Novas mídias na arte contemporânea. São Paulo: Martins Fontes, 2006.

SARZI-RIBEIRO, Regilene Aparecida. Corpo e videoarte no Brasil: desejos da parte e presenças do todo. Bauru, SP: Canal 6, 2016.

VENTURELLI, Suzete. Arte: Espaço_tempo_imagem. Brasília: Editora Universidade de Brasília, 2004. 